\title{
Targi „DZIEDZICTWO: \\ Zabezpieczenie dziedzictwa dla przyszłych pokoleń”, Kraków 10-11 X 2019 r.
}

W krakowskim klasztorze Franciszkanów po raz drugi zorganizowana została konferencja Targi Dziedzictwo, której tytułem przewodnim w tegorocznej edycji było „Zabezpieczenie dziedzictwa dla przyszłych pokoleń”. Obok franciszkanów z Krakowa organizatorem była firma Mikrofilm-Service z Raszyna. Sama idea targów ma nieco dłuższą historię, bo już od 2013 r. przez 5 lat targi organizowane były w Centrum Targowo-Konferencyjnym MT Polska w Warszawie pod nazwą: „Targi Konserwacji i Restauracji Zabytków oraz Ochrony, Wyposażenia Archiwów, Muzeów i Bibliotek DZIEDZICTWO”. Były one próbą kontynuacji i nawiązania do dobrych tradycji organizowanych w latach 2005-2007 „Targów Konserwacji i Restauracji Zabytków oraz Rewitalizacji Miast ZABYTKI”, które swym patronatem objął wówczas Generalny Konserwator Zabytków. Od 2018 r. format został przez nowych organizatorów przeniesiony do Krakowa i, podobnie jak poprzednie edycje, odbywa się w połowie października. $\mathrm{W}$ tym roku targi zostały objęte patronatem honorowym dyrektora Archiwum Akt Nowych dr. Tadeusza Krawczaka, prezydenta miasta Krakowa prof. Jacka Majchrowskiego oraz prezesa IPN dr. Jarosława Szarka.

Jak podkreślają organizatorzy wydarzenia na swojej stronie internetowej, „Targi Dziedzictwo są wydarzeniem, które ma na celu przybliżenie problemów, jakim jest zabezpieczenie Dziedzictwa Kulturowego całego naszego narodu dla przyszłych pokoleń. Jest to jedno z najważniejszych i unikalnych w Polsce wydarzeń, podczas którego spotykają się archiwiści, muzealnicy, bibliotekarze, konserwatorzy zabytków oraz eksperci z dziedziny Kultury".

W 2019 r. targi odbyły się w dniach 10-11 X. Program podzielono na panele z wykładami, które odbywały się w dwóch salach w tym samym czasie, podczas gdy wystawcy sprzętów, rozwiązań technicznych czy przedstawiciele instytucji branżowych zajęli krużganki klasztoru Franciszkanów.

\footnotetext{
1 <https://www.targidziedzictwo.pl/\#about>, [dostęp: 22.10.2019].
} 
Targi otworzył o. Łukasz Brachaczek, franciszkanin, współtwórca Targów Dziedzictwo. Słowem wprowadzenia wskazał szczególność miejsca wydarzenia, wspominając także o programie renowacji, konserwacji i digitalizacji zabytkowego księgozbioru Biblioteki Franciszkanów w Krakowie, której dyrektorem był w latach 2010-2017. Po przedstawieniu podstawowych spraw organizacyjnych, dotyczących agendy, sal wykładowych, licznie zebrani uczestnicy konferencji wzięli udział w pierwszym z zaplanowanych modułów: Archiwa.

Na początek swój wykład „Ochrona zbiorów w archiwach” przedstawiła Agnieszka Biernacka-Biesiada, przedstawicielka Działu Bibliotek i Archiwów w firmie Ceiba, zajmującej się sprzedażą produktów dla pracowni konserwacji i archiwów, zwalczania szkodników i ochrony zbiorów, a także wyposażenia bibliotek. Prelegentka zaprezentowała pokrótce historię firmy, problemy, z którymi mierzą się pracownicy bibliotek, archiwów i muzeów oraz rozwiązania, które firma Ceiba posiada w swoim bogatym portfolio, obejmującym produkty kilkunastu różnych marek. Konkluzją wystąpienia było stwierdzenie, że problem niszczenia obiektów bibliotecznych i archiwalnych stał się problemem światowym, ale na szczęście, dzięki działaniom wielu instytucji, firm oraz producentów środków zaradczych, wiemy już, w jaki sposób chronić zbiory. Powinniśmy zrobić wszystko, aby dla kolejnych pokoleń utrzymać dziedzictwo i naszą spuściznę.

W dalszej kolejności zaplanowany był wykład dra Tadeusza Krawczaka „Katecheza dziejów ojczystych. Jan Paweł II o historii Polski $(1979,1983)$ ”. Niestety, dyrektor Archiwum Akt Nowych, ze względów zdrowotnych, nie mógł osobiście wziąć udziału w konferencji, stąd jego referat został odczytany przez Dorotę Gębicką, kierowniczkę Oddziału Informacji Naukowej i Udostępniania Zasobu w AAN. Wykład w dużej mierze dotyczył dziejów narodu i Kościoła katolickiego w Polsce, poruszanych w dziełach i wystąpieniach św. Jana Pawła II. Dużo miejsca poświęcał obecnej w nauczaniu papieża historii Kościoła i państwowości w okresie staropolskim, ale też i w czasach późniejszych: uchwalenia Konstytucji 3 V, II wojny światowej, ukazywanej przez pryzmat martyrologii i dramatu ludzkości oraz roli Kościoła w tym czasie jako oparcia dla społeczeństwa w trudnych czasach. W podsumowaniu przywołano słowa papieża: „Proszę was, pozostańcie wierni temu dziedzictwu", przypominając o roli archiwistów, muzealników czy bibliotekarzy, aby zachować dziedzictwo nie tylko poprzez wiarę, ale i przez technikę. Ciekawie zreasumował wystąpienie moderator modułu, stwierdzając, że „Kościół jest piastunem przeszłości i wskazówką na przyszłość zarazem". 
Kolejnym wystąpieniem była prezentacja rozwiązań technicznych oferowanych przez firmę Koncept-L SA „Identyfikacja radiowa RFID - przełom w archiwizacji” - przedstawiona przez Piotra Rudnickiego. Firma Koncept-L jest wiodącym na rynku polskim dystrybutorem sprzętu do automatycznej identyfikacji i na nim właśnie skupiła się prezentacja. Po przedstawieniu zakresu działania i współpracy, uczestnicy poznali główny podział metod identyfikacji, wśród których wyróżniamy m.in. kody kreskowe, kody QR i wspomniany w tytule RFID. Dalej przedstawione zostały technologie odczytu, a na końcu definicje, standardy wszystkich wymienionych oraz argumenty, przemawiające za przewagą rozwiązań RFID nad pozostałymi. Jest to technika wykorzystująca fale radiowe do przesyłania danych oraz zasilania elektronicznego układu, stanowiącego etykietę obiektu, przez czytnik w celu identyfikacji obiektu. W zależności od konstrukcji pozwala na odczyt $\mathrm{z}$ odległości od kilku milimetrów do kilku metrów od anteny czytnika. Co najważniejsze, system odczytu umożliwia identyfikację wielu etykiet, znajdujących się jednocześnie w polu odczytu. Uwzględnienie tego rozwiązania w magazynach archiwalnych sprawi, że dzięki jednemu kliknięciu urządzenia będzie wiadomo, jakie materiały są zgromadzone w danym miejscu, gdzie i kiedy zostały przeniesione, itp. Można śmiało przewidywać, że jest to rozwiązanie, które w niedalekiej przyszłości trafi do archiwalnych magazynów.

Wystąpienie „Osobiste archiwa cyfrowe. Indywidualne praktyki i narzędzia zarządzania zasobami cyfrowymi” dr Anety Januszko-Szakiel należało do jednego z najciekawszych. Pani Januszko-Szakiel jest pracownikiem naukowo-dydaktycznym w Instytucie Studiów Informacyjnych Uniwersytetu Jagiellońskiego. Zajmuje się zagadnieniami długoterminowej archiwizacji zasobów cyfrowych, oceną wiarygodności archiwów cyfrowych, organizacją systemów składowania i zarządzania danych badawczych oraz metodami wyszukiwania i analizowania informacji. Jej referat skupił się na przedstawieniu uczestnikom zagadnien PDA - Personal Data Archiving, poprzez przybliżenie obszarów naszej codziennej działalności cyfrowej, „cyfrowych rzeczy”, które wytwarzamy za pośrednictwem różnego rodzaju urządzeń, technik czy chociażby stron internetowych, które przeglądamy. W półgodzinnym wystąpieniu prelegentce udało się zmieścić garść najważniejszych informacji dotyczących PDA: do czego się odnosi, co należy chronić, jakie występują trudności. Wskazała także zalecenia do skutecznego przechowywania i zarządzania archiwami osobistymi, m.in. korzystania $\mathrm{z}$ odpowiedniego rodzaju oprogramowania, konsekwentnego nazewnictwa, wielokrotności kopii i sposobów ich przechowywania. 
Referat „Doświadczenia digitalizacyjne Archiwum Państwowego w Lublinie” Marka Krzykały wypełnił kolejne pół godziny konferencji. M. Krzykała opowiedział o doświadczeniach pod kątem sprzętów do digitalizacji, które Archiwum Państwowe w Lublinie kupowało od 2002 r., kiedy nabyty został pierwszy skaner dziełowy w archiwach państwowych. Przybliżył zebranym wyzwania, które skierowały archiwum na trudną drogę wypracowania technik skanowania, metod nazewnictwa czy sposobów przechowywania wytworzonych plików cyfrowych, a które w przyszłości znalazły się w zarządzeniach, dotyczących digitalizacji czy w katalogach dobrych praktyk digitalizacyjnych. Wskazał błędy, jakie trzeba było popełnić, żeby odnaleźć właściwe rozwiązania. Historię tę wyznaczały kolejne zakupy sprzętów w 2007, 2010 i kolejnych latach, nieograniczające się wyłącznie do maszyn skanujących, ale też magazynujących dane cyfrowe. Nakreślał przy tym nowe sytuacje, w których znajdowało się archiwum, i z którymi zmuszone było sobie poradzić.

Moduł Archiwa zamykała krótka prezentacja sprzętów do digitalizacji dostępnych w ofercie firmy Mikrofilm-Service, współorganizatora Targów Dziedzictwo, dokonana przez inż. Krzysztofa Buczka, dyrektora zarządzającego firmy.

Po przerwie obiadowej przyszedł czas na drugi moduł: Biblioteki. Otworzyła go prezentacja firmy Beskid Plus - „Odporność opakowań archiwizacyjnych na ogień w testach laboratoryjnych oraz w trakcie pełnej próby pożarowej”. Piotr Tyrna, kierownik działu sprzedaży opakowań archiwizacyjnych, przedstawił kilkuminutowy film, prezentujący testy palności wykonane na różnych rodzajach pudeł tekturowych, będących w ofercie firmy, wykonanych w różnego rodzaju normach jakości. Film przedstawiał także przeprowadzoną próbę pożarową w warunkach podobnych do tych, znajdujących się niemal w każdym archiwum. Wskazał dokładnie, że nie tylko ogień jest zagrożeniem dla pudeł archiwalnych, ale przede wszystkim woda używana do gaszenia, która w zetknięciu z różnymi rodzajami tektur, w zależności od ich chłonności, może doprowadzić do ich rozpadu i zniszczenia zawartości. Wśród najważniejszych wniosków znalazło się stwierdzenie, że tektura lita celulozowa jest bardziej odporna na działanie ognia niż tektura falista, interwencja straży doprowadza do zalania oraz że można zmniejszyć skalę zniszczeń, stosując odpowiednie opakowania wykonane z tektur litych, spełniające standardy normy ISO 16245.

Drugie wystąpienie w module Biblioteki to „Funkcjonalność interfejsów zintegrowanych systemów bibliotecznych. Analiza porównawcza wybranych przykładów” dr. Stanisława Skórki z Uniwersytetu Pedagogicznego w Krako- 
wie. W prezentacji prelegent skupił się na zarysowaniu definicji zintegrowanego systemu bibliotecznego, jego architektury, funkcji katalogu i modułu OPAC (publicznie dostępny przez Internet katalog zbiorów biblioteki). Nakreślono także tzw. 8 złotych zasad interfejsu, którymi powinny się kierować dobrze prezentujące się biblioteki cyfrowe, a charakteryzujące się m.in.: dążeniem do spójności, korzystaniem ze skrótów, prostą obsługą błędów, dialogiem z użytkownikiem i wsparciem poczucia kontroli. Podsumowując przypomniał, że dobrze zaprojektowane, skuteczne systemy komputerowe wywołują pozytywne odczucia sukcesu, kompetencji, biegłości i jasności w społeczności użytkowników. Gdy system jest dobrze zaprojektowany, interfejs jest praktycznie niewidoczny, pomagając użytkownikowi skupić się na pracy, własnym badaniu lub przyjemnościach.

$\mathrm{Z}$ ostatnim tego dnia referatem „Leopoldina online - platforma integracji i udostępniania elektronicznych zasobów Uniwersytetu Wrocławskiego dla nauki, edukacji i popularyzacji wiedzy" wystąpił Michał Szala z Biblioteki Uniwersytetu Wrocławskiego. Jest to projekt realizowany w ramach Programu Operacyjnego Polska Cyfrowa na lata 2014-2020, Osi Priorytetowej nr 2 „E-administracja i otwarty rząd”, Działania nr 2.3 „Cyfrowa dostępność i użyteczność informacji sektora publicznego", mający na celu stworzenie zaplecza informatyczno-technicznego dla przechowywania, przetwarzania i udostępniania danych cyfrowych. Obejmuje także: digitalizację zasobów UWr wraz z opracowaniem merytorycznym obiektów przeznaczonych do digitalizacji i udostępniania, z uwzględnieniem opisów metadanowych i kontekstowych, a także dostawę sprzętu, audyt bezpieczeństwa i oprogramowania oraz stworzenie platformy cyfrowej www służącej integracji narzędzi wyszukiwawczych dla udostępnianych elektronicznych zasobów UWr. M. Szala w swoim referacie poprowadził uczestników konferencji przez kolejne etapy wdrażania tych rozwiązań, wskazując na użyte metody i techniki, a także zastosowane rozwiązania w zakresie wdrożonych sprzętów i urządzeń do digitalizacji, przechowywania i zarządzania plikami cyfrowymi, czy tworzenia bibliotek cyfrowych.

Pierwszy blok programowy w sekcji II dotyczył pracy prewencyjnej Państwowej Straży Pożarnej. St. bryg. dr inż. Robert Marcin Wolański, naczelnik Wydziału Centrum Szkolenia Ochrony Ludności i Ochrony Dóbr Kultury, odniósł się do wyników badań nad oceną ryzyka i przedstawił najczęstsze przyczyny pożarów w obiektach ze zbiorami dziedzictwa narodowego. I tak, największą grupę stanowi nieostrożne obchodzenie się z otwartym ogniem osób dorosłych i nieletnich, przy czym nieletni mają udział znikomy. Kolejna przyczyna to 
zwarcia instalacji i urządzeń elektrycznych oraz urządzeń ogrzewczych, brak lub nieprawidłowa konserwacja tychże. Podpalenia, w tym akty terroru, stanowią trzecią co do częstotliwości przyczynę powstawania pożarów. Pozostałe to: wyładowania atmosferyczne oraz inne, często nieustalone przyczyny.

$\mathrm{Z}$ uwagi na to, że $\mathrm{w}$ przypadku dziedzictwa każdy element ma nieocenioną wartość, skalkulowanie ryzyka wynikającego $\mathrm{z}$ wielokrotności prawdopodobieństwa strat jest w zasadzie bezcenne. Zatem stworzenie możliwie pełnego wykazu zagrożeń oraz sposobów zapobiegania staje się priorytetem dla wszystkich zainteresowanych i zobowiązanych do ochrony dóbr kulturalnych i historycznych. Przykładem takich narzędzi systemowych jest WUFI plus, służący do pełnej analizy cieplno-wilgotnościowej budynków, które było stosowane np. w Kaplicy Świętej Trójcy w Lublinie. Kolejnym etapem jest reagowanie na występujące zagrożenia. Jego skuteczność zależy zaś od poziomu zabezpieczeń i ciągłego monitorowania ich sprawności.

Bryg. mgr inż. Maciej Słodkowski, kierownik Zespołu Przedmiotowego Taktyki Zwalczania Pożarów w Wydziale Kształcenia Zawodowego w Szkole Aspirantów PSP w Krakowie, podkreślił wagę realizacji ćwiczeń ratowniczych w obiektach sakralnych. Narzucone przez rozporządzenia ministra spraw wewnętrznych i administracji oraz ministra kultury i dziedzictwa narodowego obowiązki właścicieli, zarządców i użytkowników obiektów zabytkowych, a także obowiązki PSP obligują do ochrony tychże oraz zapobiegania zagrożeniom. Skuteczność działań ratowniczych zwiększa się, gdy pracownicy PSP znają teren i obiekty oraz ich rozkład wewnętrzny, a to jest możliwe tylko dzięki ćwiczeniom, które winny się odbywać przynajmniej raz na dwa lata. Rozpoznanie dróg dojazdowych do obiektu, najbliższych ujęć wody, wystarczających do przeprowadzenia skutecznej akcji gaśniczej, jak najszybsze odnalezienie najkrótszych dróg ewakuacji ludzi, a w dalszej kolejności zagrożonego mienia staje się kluczowe, gdy w grę wchodzi czas.

Również najnowsze technologie oraz wirtualna rzeczywistość coraz częściej mają swój udział w tworzeniu narzędzi pomocnych w szkoleniach pracowników PSP. Bryg. mgr inż. Jacek Smyczyński, wykładowca w Szkole Aspirantów PSP w Krakowie, zaprezentował wyniki prac nad projektem OZAB. Stworzone narzędzie do symulowania sytuacji zagrożeń pożarowych w obiektach muzealnych i sakralnych pozwala na przećwiczenie, głównie przez strażaków i dowódców brygad strażackich, strategii działania w danych sytuacjach. System opiera się na pracy $\mathrm{w}$ wirtualnie stworzonej rzeczywistości przy pomocy gogli VR oraz padów. Całość projektu zakłada wypracowanie zachowań i reakcji podczas akcji 
ratunkowej oraz wypracowanie możliwie najlepszych metod reagowania na zagrożenia. Zadania realizowane są w formie testów zaliczeniowych.

Po przerwie obiadowej panel konserwatorski rozpoczęła przedstawicielka chorwackiej firmy KAZ d.o.o., prezentując bardzo ciekawe urządzenie osuszające zawilgocone mury. Zniszczenia powstające w wyniku podciągania wilgoci obserwujemy często w wielu obiektach zarówno zabytkowych, jak i mieszkalnych, a ich skutki, również wpływ na ludzkie zdrowie, są zbyt groźne, by problem ignorować. Rozwiązaniem, które uzyskało pozytywne opinie konserwatorów oraz zgody na osuszanie obiektów UNESCO, wydaje się być urządzenie PRO system. Wytwarza ono zewnętrzne pole elektryczne i wysyła słabe fale o niskiej częstotliwości w kierunku murów, co sprawia, że woda odwraca swój biegun, napięcie powierzchniowe spada, w rezultacie woda spływa do gruntu. System zastępuje izolację poziomą i uniemożliwia ponowne podnoszenie się wody. Duży zasięg, bardzo niskie koszty eksploatacyjne i bezobsługowość to dodatkowe atuty urządzenia, które zyskuje na popularności i jest stosowane w wielu obiektach w Polsce i na świecie.

„Sztuka konserwacji - sztuka wyboru na podstawie doświadczeń w pracy z zasobem Archiwum Akt Nowych” to luźne refleksje Magdaleny Wiercińskiej, konserwator zatrudnionej w tej instytucji. Dokument przedarty przez aktotwórcę, być może jako sprawa załatwiona - sklejać, czy może zostawić stan obecny? Ślady rdzy po elementach metalowych i związane z tym ubytki - czy stosować agresywną chemię w celu przywrócenia estetycznego wyglądu dokumentu? Kruszące się rośliny w zielniku - sklejać czy usunąć? Ręcznie robione albumy, zszyte zbyt mocno, tak że dotarcie do wszystkich informacji jest niemożliwe rozszywać? Takie i wiele innych pytań każdego dnia zadają sobie konserwatorzy archiwalni w codziennej pracy. Formułowane odpowiedzi to wynik wieloletniego doświadczenia, wiedzy, ale również umiejętność wejścia w skórę aktotwórcy, w jego czas, emocje. To także decyzja, by uratować, nie zaszkodzić. Zachować raczej obiekt niezmieniony, ograniczyć ingerencję do oczyszczenia i zabezpieczenia tak, by jak najwięcej mówił o swojej historii.

Obecne czasy to masa informacji cyfrowych. Tak bardzo wypełniają nasze życie, że przestaliśmy je zauważać. Przeglądamy masowo Internet, piszemy e-maile, SMS-y, wstawiamy posty na różnego rodzaju portalach, robimy zakupy przez Internet, pracujemy poruszając się w sieci, robimy cyfrowe zdjęcia i filmy. Jest tego tak dużo, a jednocześnie ślady są tak ulotne. Michał Murzyn z Muzeum Tatrzańskiego zastanawiał się, czy warto te treści archiwizować i na podstawie obserwacji oraz doświadczeń innych daje odpowiedź: archiwizować. 
Niektóre państwa podjęły próbę zachowania treści internetowych, ograniczając się jednak do gromadzenia danych dotyczących wyłącznie swojego kraju. Tak dzieje się np. w Skandynawii czy Stanach Zjednoczonych. W Polsce problem archiwizacji Internetu jest jeszcze w powijakach. Ze 123 najważniejszych muzeów zaledwie 9 posiada zbiory cyfrowe i je przechowuje. Mamy zatem jeszcze wiele do zrobienia w tej dziedzinie.

Postrzeganie archiwum jako urzędu służącego swoim użytkownikom to dosyć złożony temat, a upowszechnienie wiedzy o jego działalności to praca dla edukatorów archiwalnych. Hubert Mazur, m.in. na podstawie swoich doświadczeń opowiedział, jak ważne ma to znaczenie. Różnorodność form edukacyjnych jest dosyć bogata. Najczęściej spotykane to: wystawy, lekcje archiwalne, prelekcje, warsztaty, zebrania naukowe, seminaria, odczyty, konkursy czy ostatnio dosyć modne gry miejskie. Ważną rolę oczywiście odgrywają również media. Niekiedy pracownicy archiwów występują z nową, niecodzienną inicjatywą, wychodząc naprzeciw wymagającemu odbiorcy, tworząc przy tym nowe formy upowszechniania. Przykładem może być „Galeria Jezuicka 13” lubelskiego archiwum, oparta na prezentowaniu zasobu w formie ciekawostek, osobliwości. Krakowskie Archiwum Narodowe w projekcie „Dawne pismo” daje możliwość nauki czytania, tłumaczenia oraz kaligrafii fragmentów dokumentów. Z kolei archiwum szczecińskie udziela lekcji archiwalnych online, umożliwiając wygodniejsze dostosowanie czasowe i logistyczne odbiorcom. Różnorodność ofert edukacyjnych, dzięki pomysłowości i świadomości potrzeby kształcenia przyszłych pokoleń ze strony archiwów, jest zatem dosyć duża, a nowe technologie umożliwiają ich prezentowanie szerokiemu gronu zainteresowanych.

Ostatnią tego dnia prezentacją była opowieść dr. Józefa Skrabskiego o projekcie, którego celem była inwentaryzacja i digitalizacja sakralnego dziedzictwa Małopolski. Rezultatem prac jest portal internetowy, który ruszy lada chwila. $\mathrm{Z}$ pozyskanych funduszy utworzono pracownię Inwentaryzacji i Digitalizacji Zabytków Uniwersytetu Papieskiego Jana Pawła II, mieszczącą się w budynku dydaktycznym UPJPII w ramach Wydziału Historii i Dziedzictwa Kulturowego pod opieką Instytutu Historii Sztuki i Kultury. W skład zespołu, kierowanego przez prelegenta, wchodzi 14 osób, wśród których znajdują się historycy, historycy sztuki, archiwiści, fotograf i skanerzysta. Całość przedsięwzięcia rozpoczęła się w 2007 r. wyjazdami plenerowymi na terenie Małopolski w celu inwentaryzacji dzieł sztuki w obiektach sakralnych. Każdemu dziełu założono kartę inwentarzową, poddano zabiegom konserwatorskim, a następnie zdigitalizowano. Ogromowi prac, jakie przeprowadzono, towarzyszyły równie wysokie emocje. 
Niejednokrotnie okazywało się bowiem, że odkrywano niezwykle cenne obiekty, z wartości których nie zdawano sobie wcześniej sprawy. Projekt był bardzo kosztowny i czasochłonny, ale efekt na pewno jest nie do przecenienia. Należy mieć zatem nadzieję na kontynuację prac, tak by ocalić od zapomnienia i udostępnić jak najszerszemu odbiorcy to, co mamy najcenniejszego.

Drugi dzień części konferencyjnej Targów Dziedzictwo rozpoczął się w module Archiwa. Wykład pt. „Problematyka gromadzenia i zabezpieczania dziedzictwa naukowego uczelni wyższych" wygłosiła dr Magdalena Niedźwiedzka z Uniwersytetu Pedagogicznego w Krakowie. M. Niedźwiedzka już na początku zaznaczyła, że jest archiwistą teoretykiem, w dalszej części wykazała się ogromną wiedzą, dotyczącą gromadzenia materiałów o znaczeniu archiwalnym, zwłaszcza tych wytwarzanych w codziennej pracy uczelni wyższych. Przytoczyła przepisy regulujące to zagadnienie na różnych uczelniach oraz problematykę wytwarzania, gromadzenia dokumentacji i zasad dotyczących ich przechowywania oraz ewentualnego brakowania. Nie brakowało przykładów zaczerpniętych z własnych doświadczeń, m.in. traktowania spuścizn z badań naukowych, czy gromadzenia dokumentacji z badań prowadzonych na uniwersytecie.

Następnie z prezentacją „Digitalizacja materiałów archiwalnych Archiwum Akt Nowych i sposób ich udostępniania” wystąpiła Dorota Gębicka, która dzień wcześniej wygłosiła wykład w zastępstwie za dr. Tadeusza Krawczaka. Tym razem D. Gębicka poprowadziła zebranych przez historię AAN, jego działalność i charakterystykę gromadzonych materiałów, aby w dalszej części przejść do głównego zagadnienia swojego referatu. Zgromadzeni słuchacze otrzymali ciekawą historię budowy pracowni digitalizacji w Archiwum Akt Nowych, jej rozwoju poprzez zakup nowych urządzeń digitalizacyjnych, sposobu prowadzenia i organizacji prac. Podsumowując swoje wystąpienie prelegentka pochwaliła się, że do 2017 r. udostępniono w serwisie szukajwarchiwach.pl blisko 1500000 skanów z zasobu AAN, z czego 815 tys. wykonanych zostało w ramach Programu Wieloletniego Kultura+, który funkcjonował w wybranych archiwach w latach 2011-2015.

W kolejnym module, nazwanym Dziedzictwo w gminach, odbyły się trzy prezentacje. Pierwszą z nich - „Jak zbudować skuteczną strategię zarządzania dziedzictwem w erze cyfryzacji" - przedstawiła Natasza Janczak-Nadczuk z firmy KKPM Doradztwo. W swym niezwykle ciekawym wystąpieniu zapoznała uczestników z kwestią zarządzania dziedzictwem kulturowym, wskazując m.in., że jest to stałe przetwarzanie. Przykładowo, nie ma sensu digitalizacja w sytuacji, gdy nikt nie zajrzy do repozytorium. Stąd wszelkie prace należy organizować 
w taki sposób, żeby praca była zauważalna i doceniana przez odbiorcę, nie tylko przez wykonującego czy zwierzchnika. Pokazała także, że już obecnie istnieje problem z dostępem czy korzystaniem, wynikający nie tylko z braku możliwości technicznych, ale też z braku umiejętności ich obsługiwania, a sztuka zarządzania dziedzictwem, czy właśnie odpowiednia strategia zarządzania, powinna ten problem rozwiązywać.

W referacie „Od wiedzy do zarządzania: szacowanie zasobów lokalnego dziedzictwa a oddolne tworzenie baz danych i archiwów. Garść dobrych praktyk w Polsce", Aleksandra Chabiera, specjalistka ds. zarządzania dziedzictwem w Narodowym Instytucie Dziedzictwa, zaprezentowała przykłady działań oddolnych, finansowanych od kilku lat z programu „Wspólnie dla dziedzictwa”. W ciekawie prowadzonej prezentacji pokazała, że dziedzictwo kulturowe ma wpływ na nas $\mathrm{w}$ znaczeniu indywidualnym, kiedy konstytuuje naszą osobowość i kształtuje samoświadomość, ale też w społecznym, gdzie buduje poczucie wspólnoty i kształtuje tożsamość społeczną. Dziedzictwo jako element kultury społecznej buduje kapitał społeczny i tworzy sektor kreatywny, może być więc stymulatorem dla innowacyjności. Na koniec zaprezentowała świeżo wydany film prezentujący i promujący Otwarty System Archiwizacji, dostępny na stronie Archiwa Społeczne, stworzony przez Fundację Ośrodka KARTA, w którym także można uzyskać kompleksową wiedzę na temat tworzenia domowych archiwów, ich organizacji i możliwości prezentacji swoich zasobów w Internecie. Jako przykłady dobrych praktyk wskazała także działania Mazowieckiego Stowarzyszenia Pracy Osób Niepełnosprawnych DE FACTO, dążące do zmniejszania wykluczenia osób niewidzących i słabowidzących poprzez dokumentowanie i udostępnianie dziedzictwa odpowiednio dla nich (obrazy wypukłe, audiodeskrypcje, zapis w Braille'u); działania Fundacji Inicjatywa B, tworzące bibliotekę dziedzictwa kulturowego i historycznego gminy Żarów; Dom Pomorski - dziedzictwo kaszubskiej Nordy; Katalog Nepomuków.

Po przerwie obiadowej przyszedł czas na ostatni moduł: Digitalizacja $\mathrm{w}$ praktyce, w którym jako pierwsza wystąpiła przedstawicielka firmy Ceiba. W referacie „Ochrona zbiorów przed szkodnikami” kompleksowo przedstawiła etapy działań, prowadzących do rozpoznania i wyboru sposobów walki z insektami w magazynach archiwalnych, a także grzybami i pleśniami. Na kolejnych slajdach prezentacji można było zobaczyć rozwiązania techniczne stosowane przy wspomnianych zagrożeniach, prowadzące do ich całkowitej eliminacji.

W drugim dniu Targów Dziedzictwo panel biblioteczny rozpoczął się od bardzo zwięzłej prezentacji Pauliny Krupy, pt. „Zapomniane dzieła Franciszka 
Wyspiańskiego - problematyka konserwatorska rzeźb przedstawiających Marię oraz św. Jana Ewangelistę z grupy ukrzyżowania, odnalezionych w klasztorze oo. Franciszkanów w Krakowie". Autorka przedstawiła krótką biografię Franciszka Wyspiańskiego, a następnie historię odnalezienia wyżej wymienionych rzeźb, jak również zakres prac konserwatorskich, mających na celu poprawienie ich stanu oraz zabezpieczenie przed dalszą degradacją.

„Stare druki z Biblioteki Franciszkanów w Krakowie - kilka uwag o zasobie” to bardzo ciekawa relacja Alicji Łojko i Agaty Michalskiej z prac, które w zamierzeniu miały inwentaryzację, opracowanie i konserwację zbioru bibliotecznego. Określony jako cenny, księgozbiór zawiera około 660 woluminów - księgi religijne, w niewielkiej tylko części dzieła świeckie. Nie sposób tu wyliczyć różnorodności zawartości ani autorów, dość rzec, że egzemplarze zostały zewidencjonowane, poddane pracom konserwatorskim, zdigitalizowane oraz udostępnione na stronie Polona.pl

Kolejnym projektem, dotyczącym zasobów bibliotecznych, prowadzącym do digitalizacji zbiorów, a docelowo udostępnienia ich czytelnikom w wersji cyfrowej jest omówiony przez dr. Leszka Szafrańskiego, a podjęty przez Bibliotekę Uniwersytetu Jagiellońskiego. Proces digitalizacji i tworzenie kolekcji cyfrowych wymaga szczególnej organizacji i standardów. Istotne bowiem jest planowanie na wszystkich etapach tworzenia kolekcji, dbanie o zasoby, ale również o interoperacyjność z innymi systemami. Jest to szczególnie istotne ze względu na tempo zmian technologicznych. Oczywiście należy pamiętać o zgodności $\mathrm{z}$ obowiązującym prawem autorskim, ale również o przyjazności dla użytkowników. Zatem każdy etap digitalizacji winien być dobrze przemyślany i zaplanowany, również z uwzględnieniem przyszłości.

Interesującą historię biblioteki w opactwie Sióstr Benedyktynek w Staniątkach przedstawił dr Stanisław Dziedzic. Zbiory zawierają bardzo cenne woluminy (najstarszy to kancjonał z 1586 r.), które zostały zakwalifikowane do wspomnianego już projektu „Sakralne dziedzictwo Małopolski - inwentaryzacja i digitalizacja”.

Po przerwie kawowej Maciej Tarkowski zaprezentował dosyć rewolucyjne działania, a mianowicie cyfrowe rekonstrukcje historycznej architektury i tworzenie modeli 3D na podstawie zachowanych projektów hrabiego Stanisława Kostki Potockiego. W rezultacie prac tworzone jest repozytorium projektów odnalezionych, a niezrealizowanych we współpracy z Uniwersytetem Warszawskim, na systemie OMECA, które docelowo od jesieni będzie dostępne w Internecie. 
Przed przerwą obiadową przedstawiciel firmy Lenovo pokrótce omówił zagadnienie niskiej trwałości nośników cyfrowych oraz ich niewielkiej stosunkowo pojemności, a więc problem, z którym spotykają się instytucje tworzące kolekcje cyfrowe. Zaprezentował również najnowsze rozwiązania technologiczne swojej firmy.

Na koniec drugiego dnia Targów przy udziale wszystkich uczestników, o. Łukasz Brachaczek zaprezentował zdigitalizowane zbiory Biblioteki Prowincjalnej Zakonu Franciszkanów w Krakowie, udostępnione w serwisie POLONA. Opowiedział o pozyskiwaniu środków na digitalizację, opisaniu starodruków, dzięki którym dziś 2700 dzieł jest po konserwacji, oraz o przebiegu prac digitalizacyjnych. Jednocześnie podsumował dwa dni Targów Dziedzictwo, wspominając, że w tym czasie wzięło w nich udział ponad 450 osób, 36 prelegentów, 21 wystawców, dzięki czemu każdy mógł tam znaleźć coś interesującego dla siebie. Podziękował także za współpracę firmie Mikrofilm-Service z Raszyna oraz zaprosił na kolejną, trzecią edycję Targów Dziedzictwo w przyszłym roku.

$\mathrm{Z}$ założenia impreza ta ma na celu zacieśnienie współpracy pomiędzy podmiotami produkującymi oraz dystrybuującymi sprzęt i usługi specjalistyczne a konserwatorami zabytków, czy administratorami archiwów, bibliotek i muzeów. Targi składają się z części wystawowej oraz konferencyjnej, obejmującej najważniejsze i nowe zagadnienia związane $z$ tematyką archiwalną, konserwatorską, ochrony dziedzictwa, wyposażenia, zarządzania dokumentacją, jak również z pokrewnymi dziedzinami, umożliwiając implementację nowych rozwiązań i usług oraz usprawniając współpracę i wymianę doświadczeń. Mocno zadowalające jest, że - w porównaniu z poprzednią edycją - większy nacisk kładziony jest na prezentację rozwiązań technologicznych przez wystawców w formie praktycznej, nawet popularnonaukowej, a nie tylko stricte handlowej, mającej na celu jedynie zwabienie nowego klienta. Dzięki temu uczestnicy dostają praktyczne przykłady użycia, co w dalszej perspektywie przekłada się również na korzyści handlowe. Według zapewnień organizatorów, jest to właśnie ten kierunek, w którym chcą podążać, by w przyszłości umacniać Targi Dziedzictwo na mapie ważnych punktów wymiany doświadczeń i rozwiązań, na których dla instytucji $\mathrm{z}$ branży ochrony dziedzictwa kulturowego będzie wręcz ujmą nie mieć swojego przedstawiciela.

Marzanna Kędzierska, Marek Krzykała 